\title{
Thyroid Follicular Adenoma Producing Parathyroid Hormone-related Protein with a Normal Serum Calcium Level
}

\author{
Yoshiya Hosokawa ${ }^{1}$, Yuya Yamada ${ }^{1}$, Ryuya Iwamoto ${ }^{1}$, Rie Kurokawa ${ }^{1}$, Arisa Ihara ${ }^{1}$, \\ Koji Yamamoto ${ }^{1}$, Katsuhiko Sakaguchi ${ }^{2}$, Shin-ichi Nakatsuka ${ }^{3}$, Yuzo Minami ${ }^{1}$ and \\ Yuji Matsuzawa $^{1}$
}

\begin{abstract}
A 64-year-old woman had normal serum calcium and plasma parathyroid hormone levels, despite an extremely high plasma parathyroid hormone-related protein (PTHrP) level. She underwent medical screening at our hospital and several neck tumors were detected by ultrasonography. After surgical resection of these tumors, her plasma PTHrP level was normalized. Histological examination showed that the resected tumors were thyroid follicular adenomas, while immunohistochemistry revealed positive staining with a monoclonal antibody for PTHrP. This is a rare case of thyroid follicular adenoma producing PTHrP in a patient with a normal serum calcium level despite elevation of plasma PTHrP.
\end{abstract}

Key words: parathyroid hormone-related protein, thyroid follicular adenoma, calcium metabolism

(Inter Med 48: 1957-1961, 2009)

(DOI: 10.2169/internalmedicine.48.2310)

\section{Introduction}

Parathyroid hormone-related protein (PTHrP) is widely expressed in normal human tissues where it plays a role in cell proliferation and differentiation in an autocrine or paracrine fashion (1-3). PTHrP has also been reported to be the main factor associated with humoral hypercalcemia of malignancy (HHM) $(4,5)$. There are several reports showing hypercalcemia associated with high plasma PTHrP levels in patients with benign tumors (6-12). However, this is the first report, to our knowledge, of a patient with a normal serum calcium level who had a benign tumor producing PTHrP.

\section{Case Report}

A 64-year-old woman was referred to our department for evaluation of neck tumors. She had undergone medical screening every two years at our hospital. Endoscopic sur- gery for a colonic polyp had been done at the age of 46 years and she was receiving topical treatment for glaucoma. In February 2008, two neck tumors were discovered by ultrasonography during medical screening at our hospital (Fig. 1). Aspiration cytology of one of these tumors was performed, which revealed a benign follicular adenoma. The other tumor was thought to be a parathyroid gland because it was located behind the thyroid and was hypervascular and hypoechoic on ultrasonography. On admission, her height was $152 \mathrm{~cm}$, body weight was $46.3 \mathrm{~kg}$, and blood pressure was $104 / 60 \mathrm{mmHg}$. The thyroid and parathyroid glands were not palpable, and physical examination did not reveal anything abnormal. The results of routine laboratory tests are shown in Table 1. Serum calcium, inorganic phosphate and magnesium levels were normal, as were the renal fractional excretion of calcium and the renal tubular reabsorption of phosphate. Endocrine parameters are shown in Table 2. Plasma parathyroid hormone (PTH) and serum calcitonin levels were normal, but the plasma parathyroid

${ }^{1}$ Department of Endocrinology and Metabolism, Sumitomo Hospital, Osaka, ${ }^{2}$ Department of Nephrology and Hypertension, Sumitomo Hospital, Osaka and ${ }^{3}$ Department of Pathology, Sumitomo Hospital, Osaka

Received for publication March 30, 2009; Accepted for publication July 28, 2009

Correspondence to Dr. Yoshiya Hosokawa, hosokawa-yoshiya@ sumitomo-hp.or.jp 

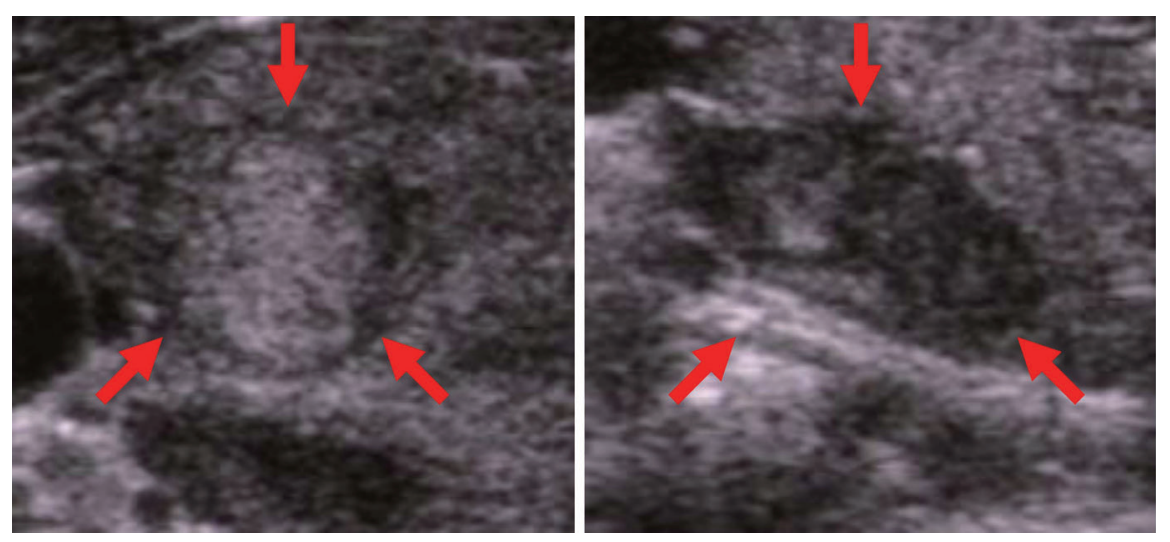

Figure 1. Ultrasonography of the cervical region showed two tumors. One represented a hyperechoic region in a right lobe of the thyroid gland (left) and the other represented a hypoechoic region behind the thyroid gland (right).

Table 1. Routine Laboratory Data

\begin{tabular}{|c|c|c|c|}
\hline Urinalysis & \multicolumn{3}{|c|}{ Chemistry } \\
\hline Protein & $(-)$ & \\
\hline Sugar & $(-)$ & \multicolumn{2}{|c|}{$\begin{array}{l}\text { Aspartate aminotransferase } 17 \mathrm{IU} / \mathrm{L} \\
\text { Alanine aminotransferase } 15 \mathrm{IU} / \mathrm{L}\end{array}$} \\
\hline FECa* & $1.51 \%$ & \\
\hline$\% \mathrm{TRP} * *$ & $91.4 \%$ & \multicolumn{2}{|c|}{$\begin{array}{l}\gamma \text {-Glutamyl transpeptidase } 13 \mathrm{IU} / \mathrm{L} \\
\text { Lactate dehydrogenase } \\
182 \mathrm{IU} / \mathrm{L}\end{array}$} \\
\hline \multicolumn{2}{|l|}{ Peripheral blood } & Albumin & $4.2 \mathrm{~g} / \mathrm{dL}$ \\
\hline Red blood cell count & $428 \times 10^{4} / \mu \mathrm{L}$ & Total cholesterol & $257 \mathrm{mg} / \mathrm{dL}$ \\
\hline Hemoglobin & $13.9 \mathrm{~g} / \mathrm{dL}$ & Triglyceride & $112 \mathrm{mg} / \mathrm{dL}$ \\
\hline Hematocrit & $41.1 \%$ & Creatinine & $0.56 \mathrm{mg} / \mathrm{dL}$ \\
\hline White blood cell count & $5900 / \mu \mathrm{L}$ & $\mathrm{Na}$ & $142 \mathrm{mEq} / \mathrm{L}$ \\
\hline \multicolumn{2}{|c|}{ (Neutrophil 69.9\%,Eosinophil 4.0\%) } & $\mathrm{K}$ & $4.6 \mathrm{mEq} / \mathrm{L}$ \\
\hline Platelet & $272 \times 10^{3} / \mu \mathrm{L}$ & $\mathrm{Ca}$ & $9.5 \mathrm{mg} / \mathrm{dL}$ \\
\hline \multicolumn{2}{|l|}{ Serological test } & inorganic $\mathrm{P}$ & $3.6 \mathrm{mg} / \mathrm{dL}$ \\
\hline \multirow[t]{2}{*}{ C-reactive protein } & \multirow[t]{2}{*}{$0.10 \mathrm{mg} / \mathrm{dL}$} & $\mathrm{Mg}$ & \multirow{2}{*}{$\begin{array}{l}2.5 \mathrm{mg} / \mathrm{dL} \\
101 \mathrm{mg} / \mathrm{dL}\end{array}$} \\
\hline & & Fasting plasma glucose & \\
\hline ctional excretion of ca & \multicolumn{3}{|c|}{$* * \%$ renal tubular reabsorption of phosphate } \\
\hline
\end{tabular}

\section{Table 2. Endocrinological Data}

\begin{tabular}{|c|c|c|c|c|}
\hline \multicolumn{5}{|c|}{ Whole parathyroid hormone $\quad 35.3 \mathrm{pg} / \mathrm{mL}$} \\
\hline \multicolumn{5}{|c|}{ Parathyroid hormone related peptide $\quad 10.8 \mathrm{pmol} / \mathrm{L}$} \\
\hline \multicolumn{5}{|c|}{ 1,25-dihydroxy vitamin $\mathrm{D}_{3} \quad 77.3 \mathrm{pg} / \mathrm{mL}$} \\
\hline \multicolumn{5}{|c|}{ Nephrogenous cyclic adenosine-3',5'-monophosphate } \\
\hline \multicolumn{5}{|c|}{ Bone specific alkaline phosphatase $\quad 33.4 \mathrm{U} / \mathrm{L}$} \\
\hline \multicolumn{5}{|c|}{ Urinary deoxypyridinoline $\quad 4.8 \mathrm{nM} / \mathrm{mM} \cdot \mathrm{Cr}$} \\
\hline Calcitonin & $24 \mathrm{pg} / \mathrm{mL}$ & \multicolumn{2}{|c|}{ Thyroid stimulating hormone } & $6.51 \mu \mathrm{IU} / \mathrm{mL}$ \\
\hline Cortisol & $11.6 \mu \mathrm{g} / \mathrm{dL}$ & \multicolumn{2}{|c|}{ Free 3, 5, 3-triiodothyronine } & $2.5 \mathrm{pg} / \mathrm{mL}$ \\
\hline Dopamin & $14 \mathrm{pg} / \mathrm{mL}$ & Free thyroxine & & $0.8 \mathrm{ng} / \mathrm{dL}$ \\
\hline Adrenaline & $57 \mathrm{pg} / \mathrm{mL}$ & Anti-thyroglobul & in antibody & $13.6 \mathrm{U} / \mathrm{mL}$ \\
\hline Noradrenaline & $608 \mathrm{pg} / \mathrm{mL}$ & Anti-thyroid perc & oxidase antibody & $>50 \mathrm{U} / \mathrm{mL}$ \\
\hline
\end{tabular}

hormone-related protein (PTHrP) level was about 10-fold higher than the normal upper limit. When the plasma PTHrP concentration was remeasured on another day, a high level (9.6 pmol/L) was still detected. Plasma PTH and PTHrP 
concentrations were measured by immunoradiometric assay using a Whole PTH IRMA kit (Scantibodies Laboratory, Inc., Santee, CA, USA) and a PTHrP IRMA kit (Mitsubishi Kagaku Latron, Inc., Tokyo), respectively. The PTHrP IRMA kit detected two sequences (amino acids 1-34 and 50-83) of the target protein (13). Thyroid stimulating hormone was slightly elevated, but the free 3, 5, 3'triiodothyronine and free thyroxine levels were within the normal range. Serum 1,25-dihydroxy vitamin $\mathrm{D}_{3}$ concentration was slightly high, and bone specific alkaline phosphatase, nephrogenous cyclic adenosine-3', 5'-monophosphate, and urinary excretion of deoxypyridinoline levels were within normal ranges. The chest X-ray film, abdominal ultrasonography findings were normal. Lumbar and femoral neck bone mineral density measured by dual energy X-ray absorptiometry were not lower than those of age-matched controls. Ultrasonography of the neck showed two tumors located in or behind the right lobe of the thyroid gland in the medical screening on admission, whereas a third tumor was discovered, situated beside the first one by ultrasonography through careful reexamination after admission. Because the thyroid gland was diffusely enlarged and antithyroglobulin antibody and anti-thyroid peroxidase antibody were positive, we diagnosed Hashimoto's disease (14). On whole-body gallium-67 scintigraphy and $18 \mathrm{~F}$ fluorodeoxyglucose positron emission tomography/computed tomography, there was no abnormal uptake and no detectable tumors. These findings suggested that a protein, which reacted with PTHrP antibody and had no effect on calcium metabolism, was present in her plasma. We termed it "PTHrP-like protein" and we considered that this protein might be secreted by the neck tumors. At the patient's consent, surgical resection of the neck tumors was performed in April 2008 at our hospital. Three encapsulated tumors were found and all of these lesions were removed without resecting normal thyroid tissue. All of the tumors were revealed to be thyroid follicular adenomas by histological examination. Immunohistochemical staining for PTHrP using mouse monoclonal anti-human PTHrP (1-34) antibody (Cosmo Bio Co, Inc., Tokyo) was positive in all of the tumors (Fig. 2). Because normal thyroid tissue was not resected, immunohistochemical staining of normal thyroid cells for PTHrP could not be done. On the next day after the operation, her plasma PTHrP level decreased to $2.6 \mathrm{pmol} / \mathrm{L}$. Two months later (June 2008), the plasma PTHrP level was below the measurable range. One year later (June 2009), serum calcium, inorganic phosphate, magnesium, 1,25-dihydroxy vitamin $\mathrm{D}_{3}$, bone specific alkaline phosphatase, plasma PTH, PTHrP and urinary deoxypyridinoline were all within the criterion value.

\section{Discussion}

In 1979, Stewart et al first used the term "humoral hypercalcemia of malignancy (HHM)" to refer to the association between malignant tumors and hypercalcemia (15). Subse-

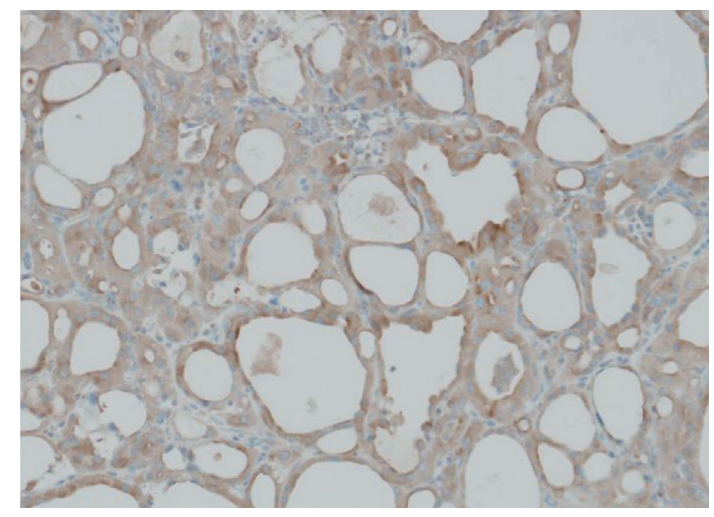

Figure 2. Immunohistochemical staining of parathyroid hormone-related protein (PTHrP) using anti-human PTHrP antibody showed positive staining (brown portion in the cytoplasma) of the thyroid follicular adenoma $(\times 200)$

quently, a peptide was purified from tumors associated with HHM. In 1987, Moseley et al referred this cancer-derived protein as PTHrP, which was considered to be the primary factor in HHM (4). On the other hand, Knecht et al defined a syndrome called humoral hypercalcemia of benignancy (HHB), in which PTHrP was secreted from benign tumors $(6,16)$. There have been some case reports of HHB associated with an ovarian dermoid cyst, massive mammary hyperplasia, pheochromocytoma, and uterine leiomyoma (612). The present patient was first revealed to have neck tumors by ultrasonography. Because of elevation of the plasma level of "PTHrP-like protein", the possibility of malignant disease was suggested and extensive work-up was performed, but no solid tumors or hematologic malignancy was detected. We reached a conclusion that the "PTHrP-like protein" was produced by her thyroid follicular adenomas, which was confirmed by its disappearance after removal of the tumors and by immunohistochemical staining of the resected specimens for anti-PTHrP antibody. Nakashima et al reported on the distribution of PTHrP in human thyroid tissues (17) after comparing 107 human thyroid tumors with 51 normal thyroid tissue samples, examining PTHrP expression by staining with a monoclonal anti-PTHrP antibody (38-64), and measuring PTHrP mRNA levels by in situ hybridization and reverse transcriptase polymerase chain reaction (RT-PCR). Both immunostaining and in situ hybridization showed that PTHrP was highly expressed in thyroid carcinomas, but not in normal thyroid tissues. Nine benign follicular adenomas were studied and only one expressed PTHrP antigen, but it was not reported whether or not the plasma PTHrP level of that patient was elevated. To our knowledge, there have been no previous case reports on patients with an elevation of the plasma PTHrP level due to a thyroid follicular adenoma. Nakashima et al concluded that the expression of PTHrP by human thyroid tissue is closely related to the malignant transformation of thyroid epithelial cells (17). In the present case, the thyroid tumors might have had the potential to undergo malignant transformation in the future. 
The normal physiologic role of PTHrP is not thoroughly understood, but it is considered to be involved in normal calcium homeostasis (18), regulation of smooth muscle (19), and regulation of tissue and organ development, differentiation, and proliferation $(1-3,20,21)$. Since PTHrP acts in an autocrine or paracrine fashion under physiological conditions, plasma PTHrP levels may not be elevated. Various forms of PTHrP, such as the N-terminal, central, and Cterminal regions, are present in the circulation of patients with HHM (22-26). The N-terminal region of PTHrP shares homology with that of PTH and binds to PTH/PTHrP receptors, leading to the onset of hypercalcemia. However, the present patient had normocalcemia despite marked elevation of the plasma PTHrP level. Fukumoto et al employed the same PTHrP IRMA kit that we used and measured plasma PTHrP levels in various patients (13). In 29 patients with HHM, the plasma PTHrP level was 1.0-34.4 pmol/L. However, 9 patients with malignancy and normocalcemia did not have levels over $2.3 \mathrm{pmol} / \mathrm{L}$ and all of their normal subjects had plasma PTHrP levels below $1.1 \mathrm{pmol} / \mathrm{L}$. They reported that the IRMA kit recognized the following sequences of PTHrP: (1-87), (1-95), (1-108), and (1-141). Accordingly, the plasma "PTHrP-like protein" in the present patient may have included the N-terminal region, which could bind to PTH/PTHrP receptors and cause hypercalcemia. This possibility is supported by the fact that the resected neck tumors of our patient were stained by a monoclonal anti-PTHrP (134) antibody. However, the serum calcium level of our patient was within normal limits. "PTHrP-like protein" in our case was inactive for the calcium metabolism. We speculated that the "PTHrP-like protein" might consist of an abnormal structure, having no ability to bind to PTH/PTHrP receptors or to transmit intracellular signaling. Because the details of the metabolism of PTHrP have not been elucidated yet, the reason why "PTHrP-like protein" was inactive remained unclear. In our case, the parameters of bone metabolism, such as lumbar and femoral neck bone mineral density, bone specific alkaline phosphatase level and urinary deoxypyridinoline excretion were not affected. Serum 1,25-dihydroxy vitamin $\mathrm{D}_{3}$ level was only slightly elevated, which fell into criterion value about one year after the removal of tumors producing "PTHrP-like protein". It was reported that the serum 1,25-dihydroxy vitamin $\mathrm{D}_{3}$ level is high in the cases of primary hyperparathyroidism, whereas it is low at any calcium level in the case of HHM. Although the reason why serum 1,25-dihydroxy vitamin $D_{3}$ concentration is suppressed in HHM has not been fully elucidated, additional factors, such as unknown cytokines from the tumors may contribute to suppress its level (27). In the patients with HHB, the serum 1,25-dihydroxy vitamin $\mathrm{D}_{3}$ concentration was reported to be low or normal $(6,10,12)$. Plasma PTH level was suppressed by the high serum calcium concentration in the patients with HHM or HHB, while the plasma PTH level was not suppressed in the present patient because of the normal calcium level, which might have, at least in part, activated vitamin $\mathrm{D}_{3}$ in our patient. In addition, there was a possibility of the effect of "PTHrP-like protein" on vitamin D activation.

In summary, we reported a patient with thyroid follicular adenomas that secreted a "PTHrP-like protein", who had a normal calcium level despite the elevation of plasma PTHrP. It will be necessary to continue monitoring the plasma level of PTHrP in this patient and to perform further analyses on her "PTHrP-like protein", such as amino acid sequence analysis.

\section{References}

1. Campos RV, Asa SL, Drucher DJ. Immunocytochemical localization of parathyroid hormone-like peptide in the rat fetus. Cancer Res 51: 6351-6357, 1991.

2. Insogna KL, Stewart AF, Morris CA, Hough LM, Milstone LM, Centrella M. Native and a synthetic analogue of the malignancyassociated parathyroid hormone-like protein have in vitro transforming growth factor-like properties. J Clin Invest 83: 10571060, 1989.

3. Kaiser SM, Laneuville P, Bernier SM, Rhim JS, Kremer R, Goltzman D. Enhanced growth of a human keratinocyte cell line induced by antisense RNA for parathyroid hormone-related peptide. J Biol Chem 267: 13623-13628, 1992.

4. Moseley JM, Kubota M, Diefenbach-Jaqqer H, et al. Parathyroid hormone-related protein purified from a human lung cancer cell line. Proc Natl Acad Sci USA 87: 5048-5052, 1987.

5. Suva LJ, Wiaslow GA, Wettenhall RE, et al. A parathyroid hormone-related protein implicated in malignant hypercalcemia: cloning and expression. Science 237: 893-896, 1987.

6. Knecht TP, Behling CA, Burton DW, Glass CK, Deftos LJ. The humoral hypercalcemia of benignancy. A newly appreciated syndrome. Am J Clin Pathol 105: 487-492, 1996.

7. Khosla S, Van Heerden JA, Gharib H, et al. Parathyroid hormonerelated protein and hypercalcemia secondary to massive mammary hyperplasia. N Engl J Med 322: 1157, 1990.

8. Kimura S, Nishimura Y, Yamaguchi K, Nagasaki K, Shimada K, Uchida H. A case of pheochromocytoma producing parathyroid hormone-related protein and presenting with hypercalcemia. J Clin Endocrinol Metab 70: 1559-1563, 1990.

9. Ravakhah K, Gover A, Mukunda BN. Humoral hypercalcemia associated with a uterine fibroid. Ann Intern Med 130: 702, 1999.

10. Bilici A, Doventas A, Karadag B, Hekim N, Tezcan V. Hypercalcemia associated with a uterine leiomyoma: a case report and review of the literature. Gynecol Oncol 93: 269-271, 2004.

11. Dagdelen S, Kalan I, Gurlek A. Humoral hypercalcemia of benignancy secondary to parathyroid hormone-related protein secreting uterine leiomyoma. Am J Med Sci 335: 407-408, 2008.

12. Mahoney CP, Cassady C, Weinberger E, et al. Humoral hypercalcemia due to an occult renal adenoma. Pediatr Nephrol 11: 339342, 1997.

13. Fukumoto S, Ikeda K, Takeuchi Y, et al. Basic and clinical studies on the measurement of plasma PTH-related protein (PTHrP) using immunoradiometric. Hormone to Rinsho (Clinical Endocrinology) 40: 1309-1314, 1992 (in Japanese).

14. Amino N. Guideline for the diagnosis of thyroid disease: Graves' disease, hypothyroidism, painless thyroiditis, chronic thyroiditis (Hashimoto's disease) and subacute thyroiditis. Hormone to Rin- 
sho (Clinical Endocrinology) 50: 643-653, 2002 (in Japanese).

15. Stewart A, Horst R, Deftos L, et al. A non-PTH renotropic factor in humoral hypercalcemia of malignancy. Clin Res 27: 377a, 1979.

16. Knecht TP, Behling CA, Burton DW, Glass CK, Deftos LJ. Humoral hypercalcaemia of "benignancy". Lancet 346: 711-712, 1995.

17. Nakashima M, Ohtsuru A, Luo WT, et al. Expression of parathyroid hormone-related peptide in human thyroid tumours. J Pathol 175: 227-236, 1995.

18. Strewler GJ. The physiology of parathyroid hormone-related protein. N Engl J Med 342: 177-185, 2000.

19. Ito M, Ohtsuru A, Enomoto $\mathrm{H}$, et al. Expression of parathyroid hormone-related peptide in relation to perturbations of gastric motility in the rat. Endocrinology 134: 1936-1942, 1994.

20. Philbrick WM, Wysolmerski JJ, Galbraith S, et al. Defining the roles of parathyroid hormone-related protein in normal physiology. Physiol Rev 76: 127-173, 1996.

21. Philbrick WM, Dreyer BE, Nakchbandi IA, Karaplis AC. Parathyroid hormone-related protein is required for tooth eruption. Proc Natl Acad Sci U S A 95: 11846-11851, 1998.

22. Burtis WJ, Brady TG, Orloff JJ, et al. Immunochemical characterization of circulating parathyroid hormone-related protein in patients with humoral hypercalcemia of cancer. N Engl J Med 322:
1106-1112, 1990.

23. Ratcliffe WA, Norbury S, Heath DA, Ratcliffe JG. Development and validation of an immunoradiometric assay of parathyrinrelated protein in unextracted plasma. Clin Chem 37: 678-685, 1991.

24. Pandian MR, Morgan CH, Carlton E, Segre GV. Modified immunoradiometric assay of parathyroid hormone-related protein: clinical application in the differential diagnosis of hypercalcemia. Clin Chem 38: 282-288, 1992.

25. Ratcliffe WA, Norbury S, Stott RA, Heath DA, Ratccliffe JG. Immunoreactivity of plasma parathyrin-related peptide: three regionspecific radioimmunoassays and a two-site immunoradiometric assay compared. Clin Chem 37: 1781-1787, 1991.

26. Orloff JJ, Reddy D, de Papp AE, Yang KH, Soifer NE, Stewart AF. Parathyroid hormone-related protein as a prohormone: posttranslational processing and receptor interactions. Endocr Rev 15: 40-60, 1994.

27. Nakayama K, Fukumoto S, Takeda S, et al. Differences in bone and vitamin $\mathrm{D}$ metabolism between primary hyperparathyroidism and malignancy-associated hypercalcemia. J Clin Endocrinol Metab 81: 607-611, 1996.

(C) 2009 The Japanese Society of Internal Medicine http://www.naika.or.jp/imindex.html 